\title{
Children's Construction of Society in Mizo and Delhi Cultures
}

\author{
Miriam Ittyerah ${ }^{*}, 1$ and Zarzokimi ${ }^{2}$ \\ ${ }^{I}$ Department of Psychology, Christ University, Bangalore- 560029, India \\ ${ }^{2}$ Department of Psychology, University of Delhi, Delhi-110007, India
}

\begin{abstract}
Mizo and Delhi children between the ages of 3 and 8 years responded to queries that emerged from six contexts, three of which were real contexts and three other pretense contexts. The study tested if young children from different cultures understand pretense and reality situations and know the use of children's reference to self, others, significant others and self with others in their narratives of reality and pretense contexts.

Content analysis of the children's narratives revealed that children from both cultures were similar in their reference to self, others, significant others and self with other. However, the reference to self and others differed in the reality and pretense contexts of both groups of children.

Findings indicate processes in children that differ in the pretense and reality situations. Furthermore, developmental differences indicate that this ability improves with age and sustains the effects of peer culture that has similarly influenced both groups of children.
\end{abstract}

Keywords: Pretense-reality, constructing society, mental representation, self.

\section{CHILDREN'S CONSTRUCTION OF SOCIETY IN MIZO AND DELHI CULTURES}

Developing competencies such as speech and the narrative mode, the mutuality of peer relations, fantasy and imagination, and a sense of morals, emerge roughly between the ages of 18 and 30 months. Children for the first time seem to have a sense of the collectivity of human society [1]. This could imply that children become socially competent. Social competence involves the recognition of self as one among other and requires some understanding of the structure of the larger society of which the individual is an inherent part. This would involve the different functions and roles which the individual may occupy [2].

With the emergence of the object concept and symbol formation, children actively see themselves as members of society [1]. In postulating an endogenous origin of society for children, Furth [1] presents a constructive - developmental perspective. The societal grasp is not merely learning from an outside model [social construction] but an internal, evolutionarily prepared development of knowledge as society.

The child becomes an agent with a will of his/her own. $\mathrm{S} /$ he also has an understanding of her/his self and that of another. The self also includes the collective self, which springs from membership in social groups: families, cliques, neighbourhood, tribes, cities, countries, region [3]. The self concept is thus extended to incorporate the other $[4,5]$.

A related area of interest in the present study is children's understanding of pretense and reality situations and how

*Address correspondence to this author at the Department of Psychology, Christ University, Hosur Road, Bangalore-560029, India; Tel: 08040129615; E-mail: miriamittyerah7@yahoo.co.in these situations can be used to convey meanings of self awareness and the awareness of the roles of others. Research has indicated [6] that even preschoolers appear to have a grasp of the distinction between imagined and real entities. Furthermore young children's pretend play is considered to display the development of collective intentionality [7] which is an essentially socially and culturally acquired form of action involving shared cooperation and some rudimentary forms of joint creation of status functions.

The present study also tests for children's ability to narrate about themselves in the context of pretense and reality situations and to compare the narratives of children from the cultures of Delhi and Mizoram, one of which is predominantly urban and the other tribal. Evidence indicates that children have an early understanding of pretense and reality situations [8] and are able to perform pretend and reality tasks in similar situations as early as one and two years of age [9]. The rationale for choosing children from the two cities is to know how the cultural contexts in which the children live influence their understanding of their self and subsequent social interaction.

\section{METHOD}

\section{Subjects}

The subjects in the study comprised of a total of 48 children between the ages of 3 years and 8 years, from two cities with different cultural backgrounds - Delhi and Mizoram. An equal number of children were taken from both cities with equal numbers of boys and girls from each age group, there being in all 24 children from each city, with 2 boys and 2 girls at each age level. The 24 children from Delhi were normal children and belonged to urban, middle class families (a family income of Rs. 20,000/- to Rs. 
$35,000 /-$ per month). They were all conversant in the Hindi language though some older children were conversant in English language as well. The 24 Mizo children were normal children from urban middle class families and belonged to the Mizo community in Aizawl, the capital of the state of Mizoram. They were conversant in the Mizo language and found no difficulty in understanding the tasks that were instructed in this language.

\section{Tasks and Procedure}

The study was conducted by presenting 6 contexts to each child, three of these were reality contexts and three others were pretense contexts. Although two of the three pretense tasks contained real life situations, the instructions to subjects such as 'let us pretend' before the presentation of each pretense task was considered to be most important in differentiating the pretense task from the reality task. The six tasks were formulated keeping in mind the ease of understanding that is required for all the subjects, including the very young children. All the six contexts from which the stories emerged were neutral in so far as they did not refer to particular cultural norms, such as festivals or rituals of any group of people.

The reality tasks were mainly real life situation contexts and are presented below.

The $1^{\text {st }}$ reality task: "Summer is a hot season and everyone feels hot during this time of the year. How about you? Do you feel hot in summer? Tell me what you do when you feel hot in the summer".

The $2^{\text {nd }}$ reality task: "We all bathe to stay clean and healthy. How about you? Do you bathe regularly? Tell me what you do when you bathe."

The $3^{\text {rd }}$ reality task: "We all eat food for energy and health. How about you? Do you eat regularly? Tell me about the way you eat your meals."

The pretense tasks were the following and required the child to pretend about each situation.

The $1^{\text {st }}$ pretense task: "Let us pretend that today is your friend's birthday. S/he has invited you along with other friends for a party at her/his house. Tell me how you will prepare for the party and what you will do at the party."

The $2^{\text {nd }}$ pretense task: "Let us pretend you have a pet [any animal] and one day as you are playing with your pet, it accidentally breaks its leg. Tell me what you would do to heal the pet's broken leg."

The $3^{\text {rd }}$ pretense task: "Let us pretend you are a great king/queen. You are the ruler of a big country where many people live. Tell me how you will rule the country and how you will deal with your subjects".

All the children were tested individually. Every child was presented each story and asked to narrate about each story situation. Additional probe questions were used when the children were not forthcoming with their responses. For example, when a three year old was asked "Do you bathe regularly? Tell me what you do when you bathe", the response elicited was just a "yes", so probe questions like "who bathes you?", "How?", “And?” etc. were used to elicit more responses.
The narratives of the children were recorded verbatim in writing and content analysis [10] was used to study these narratives. The schematic representation of the categories and the units of analysis are presented in Table $\mathbf{1}$.

Table 1. Schematic Representation of Categories and Units of Analysis

\begin{tabular}{|c|c|}
\hline Categories & Units of Analysis \\
\hline \hline Reference to self & I, Me, My, Myself \\
\hline Reference to others & He, she, they, friends, doctor, nurse etc. \\
\hline $\begin{array}{c}\text { Reference to } \\
\text { significant others }\end{array}$ & $\begin{array}{c}\text { Mother, Father, Brother, Sister, Aunt, Uncle, } \\
\text { Cousins, Grandparents }\end{array}$ \\
\hline $\begin{array}{c}\text { Reference to self } \\
\text { with others }\end{array}$ & We, Us, Our \\
\hline
\end{tabular}

\section{RESULTS}

Content analysis [10] was done and the units of analysis based on the four specified categories - reference to self, reference to significant others, reference to self with others and reference to others - were noted and the frequencies of these units of analysis were tabulated.

Table 2 shows the means and standard deviations of the Delhi and Mizo children for the reality tasks.

Table 2. Means and Standard Deviations [in brackets] of Delhi and Mizo Children for the Reality Tasks

\begin{tabular}{|c|c|c|c|c|}
\hline Culture & $\begin{array}{c}\text { Reference } \\
\text { to Self }\end{array}$ & $\begin{array}{c}\text { Reference } \\
\text { to others }\end{array}$ & $\begin{array}{c}\text { Reference to } \\
\text { significant } \\
\text { others }\end{array}$ & $\begin{array}{c}\text { Reference to } \\
\text { self with } \\
\text { others }\end{array}$ \\
\hline \hline Delhi & $12.65[4.8]$ & $0.45[0.6]$ & $4.90[2.1]$ & $1.40[1.2]$ \\
\hline Mizoram & $12.75[3.3]$ & $0.60[0.5]$ & $4.60[2.1]$ & $1[1.1]$ \\
\hline
\end{tabular}

Table 2 indicates that there seems little difference in the means of the Delhi and Mizo children for the reality tasks. The similarity between the narratives of the two cultures is present in the pretense tasks as well (see Table $\mathbf{3}$ ).

Table 3. Means and Standard Deviations [in brackets] of Delhi and Mizoram Children in the Pretense Tasks

\begin{tabular}{|c|c|c|c|c|}
\hline Culture & $\begin{array}{c}\text { Reference } \\
\text { to Self }\end{array}$ & $\begin{array}{c}\text { Reference } \\
\text { to others }\end{array}$ & $\begin{array}{c}\text { Reference to } \\
\text { significant } \\
\text { others }\end{array}$ & $\begin{array}{c}\text { Reference } \\
\text { to self with } \\
\text { others }\end{array}$ \\
\hline \hline Delhi & $9.70[3.8]$ & $7.20[3.8]$ & $1.80[0.8]$ & $1.90[0.8]$ \\
\hline Mizoram & $8.85[4.0]$ & $6.85[3.4]$ & $1.90[0.9]$ & $2.45[1.0]$ \\
\hline
\end{tabular}

Examination of the means of the reality and pretense tasks show that for the reality task, there were more responses to the self and significant others [mother, sister], whereas for the pretense tasks there were more references to 'others' [doctor, friend] for both groups of children.

Chi-square tests computed with the frequency of responses indicated no differences between the Delhi and Mizo children for the reality $\left(\mathrm{c}^{2}=1.5, \mathrm{df}=3, \mathrm{p}\right.$. n. s). nor the 
pretense tasks $\left(\mathrm{c}^{2}=3.12, \mathrm{df}=3, \mathrm{p} . \mathrm{n}\right.$. s. $)$ indicating that the two groups of children do not differ in their references to the individual and collective self.

However, there were differences between the reality and pretense narratives of the children $\left(\mathrm{c}^{2}=365.3, \mathrm{df}=3, \mathrm{p}<\right.$ 0.01 ). The differences between the reality and pretense narratives were significant for the Mizo children $\left(\mathrm{c}^{2}=167.8\right.$, $\mathrm{df}=3, \mathrm{p}<0.01)$ as well as the Delhi children $\left(\mathrm{c}^{2}=187.75\right.$, $\mathrm{df}=3, \mathrm{p}<0.01$ ) indicating that children from both cultures referred to 'self' and 'significant others' more often than that of the other categories in the reality situations, and more to 'others' and 'self with other' in the pretense situations.

Table 4 shows the means and standard deviations for age in the reality tasks.

Table 4. Means and Standard Deviations for each Age Group in the Reality Tasks

\begin{tabular}{|c|c|c|c|c|}
\hline $\begin{array}{c}\text { Age } \\
\text { Group }\end{array}$ & $\begin{array}{c}\text { Reference } \\
\text { to self }\end{array}$ & $\begin{array}{c}\text { Reference } \\
\text { to others }\end{array}$ & $\begin{array}{c}\text { Reference to } \\
\text { significant } \\
\text { others }\end{array}$ & $\begin{array}{c}\text { Reference } \\
\text { to self with } \\
\text { others }\end{array}$ \\
\hline \hline 3 years & $7.40[1.9]$ & nil & $6.50[1.1]$ & $0.13[0.3]$ \\
\hline 4 years & $10.50[2.78]$ & nil & $6.25[1.9]$ & $0.13[0.4]$ \\
\hline 5 years & $12.60[1.49]$ & $0.10[0.3]$ & $6.25[1.3]$ & $0.13[0.7]$ \\
\hline 6 years & $12.80[2.4]$ & $0.75[0.5]$ & $3.40[1.2]$ & $1.80[0.9]$ \\
\hline 7 years & $15.30[3.07]$ & $1[0.5]$ & $2.90[1.7]$ & $1.80[1.6]$ \\
\hline 8 years & $17.60[3.15]$ & $1.25[0.5]$ & $3.13[0.9]$ & $2.25[1.2]$ \\
\hline
\end{tabular}

Table 4 shows that the children's reference to self and reference to self with significant others increased with age. The means and standard deviations for each age group in the pretense tasks are presented in Table $\mathbf{5}$.

Table 5. Means and Standard Deviations for each Age Group in the Pretense Tasks

\begin{tabular}{|c|c|c|c|c|}
\hline $\begin{array}{c}\text { Age } \\
\text { Group }\end{array}$ & $\begin{array}{c}\text { Reference } \\
\text { to self }\end{array}$ & $\begin{array}{c}\text { Reference } \\
\text { to others }\end{array}$ & $\begin{array}{c}\text { Reference to } \\
\text { significant } \\
\text { others }\end{array}$ & $\begin{array}{c}\text { Reference } \\
\text { to self with } \\
\text { others }\end{array}$ \\
\hline \hline 3 years & $3.00[1.2]$ & $1.500[0.16]$ & $2.4[0.7]$ & $1.60[0.5]$ \\
\hline 4 years & $8.25[2.04]$ & $4.25[1.1]$ & $2.13[1.01]$ & $1.75[0.8]$ \\
\hline 5 years & $8.50[2.5]$ & $6.25[1.2]$ & $1.90[0.3]$ & $2.40[0.9]$ \\
\hline 6 years & $10.60[2.2]$ & $8.40[1.5]$ & $1.90[0.8]$ & $2.00[0.7]$ \\
\hline 7 years & $11.25[2.04]$ & $10.13[2.9]$ & $1.40[1.1]$ & $2.13[0.7]$ \\
\hline 8 years & $13.90[2.02]$ & $11.25[2.10]$ & $1.50[0.7]$ & $3.13[1.2]$ \\
\hline
\end{tabular}

Chi square $\left(\mathrm{c}^{2}\right)$ indicated significant differences in age for both the reality $\left(\mathrm{c}^{2}=95.23, \mathrm{df}=15, \mathrm{p}<0.01\right)$ and pretense tasks $\left(\mathrm{c}^{2}=56.21, \mathrm{df}=15, \mathrm{p}<0.01\right)$. In the reality tasks, reference to self and "significant others" increased with age. In the pretense task, children of all age groups referred more to "self" and to "others". Children's reference to "significant others" decreased with age while their reference to "self with others" and "others" increased with age in the pretense context.

\section{NARRATIVES}

The narratives indicate the similarity of thought in children from the two different cultures. Both children refer to the self and significant others in the reality situations, whereas in the pretense situations they are able to relate the self with others. These similarities indicate that the children's choice of items and responses seem to be influenced by their peer culture than by the parent culture of the past.

\section{DISCUSSION}

The primary findings of the study indicate no differences between the children of the two cultures in their reference to the individual or the collective self, in both the reality and pretense narratives. This finding may be attributed to the fact that even though Aizawl (Mizo) society is predominantly tribal, the ever growing urban character may have led to the encroachment of market driven forces, affecting a change in the early tribal characteristics of cooperation, community activities and a sense of group cohesion. Howrigan [11] indicated that the peer groups of adults can influence each other to bring about changes in their traditional cultural practices of child rearing. Mexican mothers were observed to change from breast feeding their infants to bottle feeding practices [11], and in Kenya, the Gusii infants were no longer force fed millet gruel by blocking their nostrils [12]. Besides children of a certain social class who live in the same neighbour hood and go to the same school are likely to be reared by parents who share common child rearing methods [13]. Harris [14] argued that socialization is context specific and outside the home socialization takes place in the peer groups of children and adolescents.

Developmental differences in the narratives of the children in both the reality and pretense situations indicate that children in the different age groups differed in their reference to the self, others, significant others and self with others. Whereas younger children refer to significant others, reference to others and self with others increased with age, indicating that by 5 years children have an understanding of a wider social network. Children can also be influenced by the effects of media such as television or magazines. Lasater and Johnson [15] agree that cultural transmission to individual children passes through the filter of children's group. Therefore peer groups create their own culture [13].

The results of the study also indicate that significant differences exist between the reality and pretense narratives for both the Mizo and Delhi children. There was no ambiguity in the children's representations of mental objects in both the reality and pretense narratives. Racokszy [7] found that children as young as two and three years understand joint pretense games and are able to detect violations in these games. In summary the findings suggest that children from both cultures - Mizoram and Delhi - are active participants and co-constructors of society.

\section{ACKNOWLEDGEMENTS}

The authors thank both groups of children for their interest and patience. 


\section{REFERENCES}

[1] Furth H.G. The Instinct for Society. Children's Knowledge as Social Imaginations. Plenum Press, 1996.

[2] McGurk $\mathrm{H}$ [Ed], Issues in Childhood Social Development. Metheun \& Co, Ltd, London, 1978.

[3] Baumeister RF, Leary MR. The need to belong: Desire for interpersonal attachments as a fundamental human motivation. Psychological Bulletin 1995; 117: 497-529.

[4] Rogers C. The child's perception of other people. In H. Mc Gurk [Ed.], Issues in Childhood Social Development. Metheun \& Co, Ltd, London, 1978.

[5] Walsh WA, Banaji MR. The Collective Self. In J.G. Snodgrass \& R.L.Thompson [Eds.], The Self Across Psychology: SelfRecognition, Self- Awareness, and the Self Concept. Annals of The New York Academy of Sciences. The New York Academy of Sciences, New York, New York, 1997; Vol, 818. pp. 193-214.

[6] Wellman HM, Estes D. Early understanding of mental entities: A reexamination of childhood realism. Child Development 1986; 17: 910-23.

[7] Rakoczy H. Taking Fiction Seriously: Young Children Understand the Normative Structure of Joint Pretence Games. Development Psychol 2008; 44: 1195-201.

[8] Bourchier A, Davis A. Children's understanding of the pretencereality distinction: a review of current theory and evidence. Developmental Science 2002; 5: 397- 41.
Bosco F M, Friedman O, Leslie A M. Recognition of pretend and real actions in play by 1- and 2-year-olds: Early success and why they fail. Cognitive Development 2005; 21: 3-10.

[10] Holsti OR. Content Analysis. In G. Lindzey \& E. Aronson [Eds.] The Handbook of Social Psychology, Research Methodology, Addison, Wesley Publishing Company, 1968; Vol, 2, pp. 596-692.

[11] Howrigan GA. Fertility, infant feeding, and change in Yucatán. In R. A. LeVine, P. M. Miller, \& M. M. West [Eds.]. Parental behavior in diverse societies. New Directions for Child Development. San Francisco: Jossey-Bass, 1988; No. 40: pp. 3750 .

[12] LeVine RA, LeVine SE [1988]. Parental strategies among the Gusii of Kenya. In R. A. LeVine, P. M. Miller, \& M. M. West [Eds.], Parental behavior in diverse societies. New Directions for Child Development. San Francisco: Jossey-Bass, 1998; No. 40: pp. 2735.

[13] Corsaro W A. Discussion, debate, and friendship processes: Peer discourse in US and Italian nursery schools. Sociology of Education 1994; 67: 1-26.

[14] Harris RJ. Where is the child's environment? A group socialization theory of development. Psychological Review 1995: 102: 458-489.

[15] Lasater C. \& Johnson J E. Culture, play, and early childhood education. In J. L. Roopnarine, J. E. Johnson, \& F. H. Hooper [Eds.], Children's play in diverse cultures. Albany: State University of New York Press, 1994;.pp. 210-28

(C) Ittyerah and Zarzokimi; Licensee Bentham Open.

This is an open access article licensed under the terms of the Creative Commons Attribution Non-Commercial License (http://creativecommons.org/licenses/by$\mathrm{nc} / 3.0 /$ ), which permits unrestricted, non-commercial use, distribution and reproduction in any medium, provided the work is properly cited. 